\title{
Effect of Natural Flavouring Agents and Storage Conditions on Physicochemical Properties and Viability of Probiotic Lactic Acid Bacteria Incorporated into Tigernut-Milk Drink
}

\author{
FS Ire, N Maduka* and HO Njoku \\ Department of Microbiology, University of Port Harcourt, Nigeria
}

Submission: May 06, 2017; Published: May 30, 2017

"Corresponding author: N Maduka, Department of Microbiology, Faculty of Science, University of Port Harcourt, Nigeria, Email: maduks.mn@gmail.com

\begin{abstract}
Addition of natural flavouring agents to locally produced beverages and consumption of probiotic products is a strategy aimed at reducing overdependence in chemically synthesized flavouring agents and beverages. This study evaluated the effect of two storage conditions as well as two flavouring agents in the physicochemical properties and viability of probiotic lactic acid bacteria incorporated into tigernut-milk drink. Mixed culture lactic acid bacteria (LAB) comprising Lactobacillus plantarum, Lactobacillus acidophilus, Streptococcus thermophilus and Lactobacillus brevis isolated from ogi were introduced into tigernut-milk drink, flavoured separately with $3 \%(\mathrm{w} / \mathrm{v})$ ginger, $5 \%(\mathrm{w} / \mathrm{v})$ ginger, $3 \%(\mathrm{w} / \mathrm{v})$ garlic and $5 \%(\mathrm{w} / \mathrm{v})$ garlic and stored at refrigeration $\left(4 \pm 2{ }^{\circ} \mathrm{C}\right)$ and ambient temperature $\left(28 \pm 2{ }^{\circ} \mathrm{C}\right)$ for 12 weeks. Non-flavoured tigernut-milk drink was used as control. During storage of the flavoured and non-flavoured lactic acid bacterial tigernut-milk drink, there was increase in percentage titratable acidity (\% TTA), LAB count, total heterotrophic bacterial count and lactic acid produced by the four species of LAB but reduction in pH. Based on standard set by Codex Alimentarius regarding safe dairy milk and recommended minimum of biovalue (MBV), the $5 \%(\mathrm{w} / \mathrm{v})$ garlic flavoured tiger nut-milk drink stored at both storage conditions and $5 \%(\mathrm{w} / \mathrm{v})$ ginger flavoured tigernutmilk drink stored at refrigeration temperature were considered safe probiotic products at Week 12 . All the lactic acid bacterial tigernut-milk drink preparations at Week 8 met the criteria. Non-flavoured tigernut-milk drink maintained highest LAB count and its shelf life is 8 weeks. Ambient and refrigeration temperature favour probiotic stability while refrigeration temperature storage and flavouring agents prolonged the shelf life of these products.
\end{abstract}

Keywords: Flavouring agent; Lactic acid bacteria; Minimum of biovalue; Probiotic; Tigernut drink

\section{Introduction}

Tigernut drink is an energetic, diuretic, whitish beverage rich in nutrients and minerals prepared using tigernut tubers $[1,2]$. It is considered as a medicinal drink. Tigernut drink can be used to develop a yoghurt-like product $[3,4]$. A good yoghurt is an example of a probiotic product. Tigernut drink can be subjected to spontaneous fermentation by its natural flora [5]. Using tigernut extract, [6] was able to produce probiotic yoghurt. Commercially, the production of yoghurt involves a ready-to-use starter culture of lactic acid bacteria. In many countries, packaged probiotic products are popular but traditionally fermented products is the major source of probiotics in Nigeria [7]. Yoghurt of different flavours such as vanilla, strawberry etc. is readily available as a variety to traditional sour tasty yoghurt [8-10]. Many flavouring agents added to yoghurt are chemically synthesized which has lower nutritive value compared to natural flavouring agents such as ginger (Zingiber officinale Rosc.) and garlic (Allium sativum
L.) which also has therapeutic benefits [11-13]. Spices are easily identified by its aromatic or strong taste [14]. Adding spices to beverages improves taste. It also adds flavour and aroma. Spices can function as a food preservative by inhibiting growth of some spoilage microbes. Adding spices as flavouring agent to probiotic tigernut drink and storage conditions such as refrigerated storage temperature can affect the viability of probiotic lactic acid bacteria in probiotic yoghurt [15-17]. The level of activity of LAB in the tigernut drink is indicated by physicochemical parameters such as lactic acid produced, $\mathrm{pH}$ and TTA in addition to LAB count [15]. Shelf life studies of edible products involves monitoring total heterotrophic bacterial count in the product among other parameters considering standards set by relevant regulatory bodies [18]. Although a universally acceptable minimum of biovalue (MBV) of viable probiotic microbial cells in a probiotic product had not been adopted, the food industry recommends $1 \times 106 \mathrm{cfu} \mathrm{ml}^{-1}$. Daily dose of about 3-5 billion live 
probiotic bacteria is recommended for human consumption [19]. At the end of shelf life of a probiotic product, the functional level of live LAB should be $106-107 \mathrm{cfu} / \mathrm{ml}$ [20]. This study is aimed at determining the effect of two flavouring agents and storage conditions on the viability of LAB that had been incorporated into tigernut-milk drink and its physicochemical properties as a potential probiotic product.

\section{Materials and Methods}

Big yellow variety Tigernut tubers, ginger, garlic and freshly prepared ogi were purchased from Oshodi Market Lagos State.

\section{Preparation of tigernut-milk drink}

The fresh big yellow variety of tigernut tubers was used to produce tigernut-milk drink using slightly modified method described by [5].

\section{Preparation of lactic acid bacteria fermented tigernut- milk drink using LAB isolates from ogi}

deMan, Rogosa and Sharpe (MRS) agar was used to isolate lactic acid bacteria (LAB) from ogi. Morphology of the colonies was noted. Gram staining and test for catalase was carried out on the isolates. Using the procedure of [21], specie name of the isolates were confirmed using API 50 CHL (Biomerieux®, France) carbohydrate profiling following manufacturer's instruction. A slightly modified method described by [5] was adopted in preparing mixed culture lactic acid bacterial inoculum comprising four bacterial isolates from ogi identified as Lactobacillus plantarum, Lactobacillus acidophilus, Streptococcus thermophilus and Lactobacillus brevis. The already prepared tigernut-milk drink contained in four separate Erlenmeyer bottles was pasteurized at $72{ }^{\circ} \mathrm{C}$ for 15 minutes. A mixed culture of $2 \%(\mathrm{w} / \mathrm{v})$ lactic acid bacteria species namely Lactobacillus plantarum, Lactobacillus acidophilus, Streptococcus thermophilus and Lactobacillus brevis was introduced into six separate Erlenmeyer bottles containing $500 \mathrm{ml}$ pasteurized tigernut-milk drink.

\section{Preparation of garlic and ginger flavoured lactic acid bacteria fermented tigernut-milk drink}

The method of $[22,23]$ was adopted in preparing $3 \%(\mathrm{w} / \mathrm{v})$ and $5 \%(\mathrm{w} / \mathrm{v})$ ginger; $3 \%(\mathrm{w} / \mathrm{v})$ and $5 \%(\mathrm{w} / \mathrm{v})$ garlic flavouring agents. Each flavouring agent of a particular concentration was mixed with $500 \mathrm{ml}$ pasteurized lactic acid bacteria tigernut-milk drink. A set of non-flavoured pasteurized lactic acid bacteria tigernut-milk drink is control.

\section{Storage of garlic and ginger flavoured lactic acid bacteria fermented tigernut-milk drink}

Duplicate samples of lactic acid bacteria fermented tigernutmilk drink of ginger flavour in two concentrations $3 \%(\mathrm{w} / \mathrm{v})$ and $5 \%(\mathrm{w} / \mathrm{v})$ were prepared. Similarly, duplicate samples of lactic acid bacteria fermented tigernut-milk drink of garlic flavour in two concentrations $3 \%(\mathrm{w} / \mathrm{v})$ and $5 \%(\mathrm{w} / \mathrm{v})$ were also prepared. Duplicate sample of non-flavoured tigernut-milk drink without any flavouring agent added is control. Each of the lactic acid bacteria fermented tigernut-milk drink composition was stored at ambient temperature and the duplicate sample stored at refrigeration temperature for 12 weeks. The $\mathrm{pH}$, \%TTA, total culturable lactic acid bacterial count, percentage lactic acid produced and total heterotrophic bacterial count in the flavoured and non-flavoured lactic acid bacteria fermented tigernut-milk drink was monitored at 4 weeks interval for a period of 12 weeks.

\section{Results}

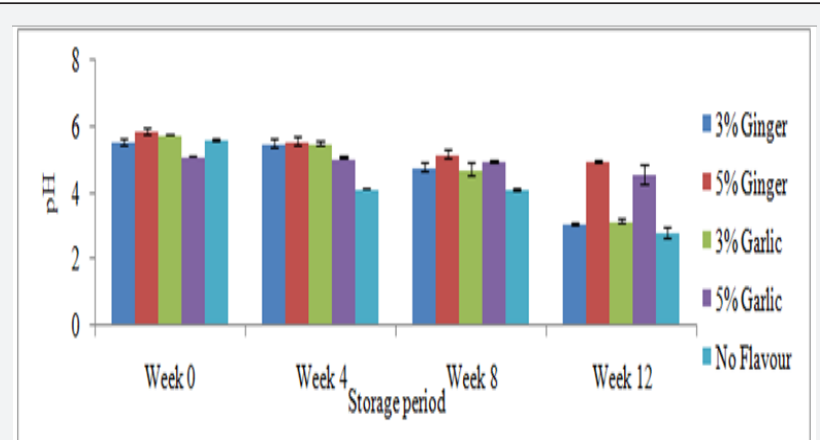

Figure 1: The $\mathrm{pH}$ of flavoured and non-flavoured lactic acid bacterial tigernut-milk drink stored at refrigeration temperature.

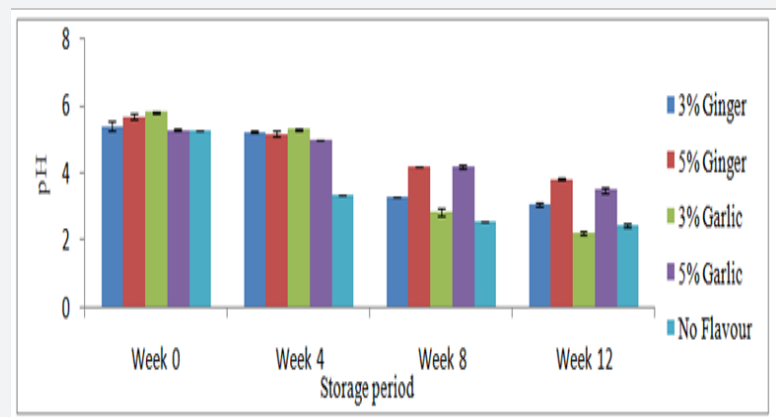

Figure 2: The $\mathrm{pH}$ of flavoured and non-flavoured lactic acid bacterial tigernut-milk drink stored at ambient temperature.

Figure 1 shows the $\mathrm{pH}$ of flavoured and non-flavoured lactic acid bacterial tigernut-milk drink stored at refrigeration temperature while Figure 2 depicts the $\mathrm{pH}$ of flavoured and non-flavoured lactic acid bacterial tigernut-milk drink. These results indicated that there was reduction in $\mathrm{pH}$ in the flavoured and non-flavoured lactic acid bacterial tigernut-milk drink during refrigeration and ambient temperature storage. During refrigeration temperature storage, the non-flavoured lactic acid bacterial tigernut-milk drink had the lowest $\mathrm{pH}$ except at Week 0 when $5 \%(\mathrm{w} / \mathrm{v})$ garlic flavoured lactic acid bacterial tigernutmilk drink had the lowest $\mathrm{pH}$. Throughout ambient temperature storage period, Figure 2 shows that non-flavoured lactic acid bacterial tigernut-milk drink maintained the lowest $\mathrm{pH}$ except $3 \%(\mathrm{w} / \mathrm{v})$ garlic flavoured lactic acid bacterial tigernut-milk drink at Week 12 which had the lowest pH. The absence of ginger or garlic which exhibit antimicrobial properties capable 
of inhibiting growth of LAB present in the non-flavoured lactic acid bacterial tigernut-milk drink could be the reason for its consistent lower $\mathrm{pH}$ than the ginger and garlic flavoured lactic acid bacterial tigernut-milk drink during the storage period. At Week 0 , the relatively high $\mathrm{pH}$ of both flavoured and nonflavoured lactic acid bacterial tigernut-milk drink which steadily decreased as storage period increased could be as a result of LAB present in the tigernut-milk drink being at the lag phase.

It is obvious in Figure $1 \& 2$ that a significant reduction in $\mathrm{pH}$ occurred at Week 12 during refrigeration temperature storage whereas it occurred earlier at Week 8 during ambient temperature storage except in lactic acid bacterial tigernut-milk drink flavoured with $5 \%(\mathrm{w} / \mathrm{v})$ ginger and $5 \%(\mathrm{w} / \mathrm{v})$ garlic. The reason for high $\mathrm{pH}$ in the $5 \%(\mathrm{w} / \mathrm{v})$ ginger flavoured and $5 \%(\mathrm{w} / \mathrm{v})$ garlic flavoured lactic acid bacterial tigernut-milk drink could be as a result of high concentration of antimicrobial substances in $5 \%(\mathrm{w} / \mathrm{v})$ ginger and $5 \%(\mathrm{w} / \mathrm{v})$ garlic which inhibited growth of LAB in the lactic acid bacterial tigernut-milk drink compared with the $3 \%(\mathrm{w} / \mathrm{v})$ ginger flavoured and $3 \%(\mathrm{w} / \mathrm{v})$ garlic flavoured lactic acid bacterial tigernut-milk drink which contain lower concentration of ginger and garlic. Reduction in $\mathrm{pH}$ as storage period increased is similar to result reported by $[5,24]$. Throughout the storage period at both storage conditions, low $\mathrm{pH}$ of all the lactic acid bacterial tigernut-milk drink preparations did not limit growth of LAB nor did it greatly affect probiotic stability contrary to assertion by [25] that very low pH could reduce viability of probiotic bacteria. In a related study carried out by [26] to determine the suitability of using African yam bean as a non-dairy probiotic beverage, they observed that there was decrease in $\mathrm{pH}$ and increase in TTA of the beverage during storage at refrigeration and ambient temperature.

Table $1 \& 2$ shows the percentage titratable acidity of both flavoured and non-flavoured lactic acid bacterial tigernutmilk drink monitored at 4 weeks interval during storage at refrigeration and ambient temperature, respectively for 12 weeks. During refrigeration and ambient temperature storage, there was increase in percentage titratable acidity possibly as a result of acidification due to activities of dominant lactic acid bacteria present in both flavoured and non-flavoured tigernutmilk drink [24]. Usually, during lactic acid bacteria fermentation, reduction in $\mathrm{pH}$ is accompanied with higher percentage titratable acidity [5].

Table 1: Titratable acidity (\%) of flavoured and non-flavoured lactic acid bacterial tigernut-milk drink stored at refrigeration temperature.

\begin{tabular}{|c|c|c|c|c|c|}
\hline Week & $\mathbf{3 \%}$ Ginger & $\mathbf{5 \%}$ Ginger & $\mathbf{3 \%}$ Garlic & $\mathbf{5 \%}$ Garlic & No Flavour \\
\hline 0 & $7.55 \pm 0.031^{\mathrm{a}}$ & $6.48 \pm 0.025^{\mathrm{a}}$ & $6.45 \pm 0.025^{\mathrm{a}}$ & $6.04 \pm 0.025^{\mathrm{a}}$ & $6.27 \pm 0.0265^{\mathrm{a}}$ \\
\hline 4 & $8.19 \pm 0.020^{\mathrm{b}}$ & $6.68 \pm 0.085^{\mathrm{b}}$ & $6.67 \pm 0.020^{\mathrm{b}}$ & $6.30 \pm 0.021^{\mathrm{b}}$ & $8.39 \pm 0.035^{\mathrm{b}}$ \\
\hline 8 & $9.37 \pm 0.021^{\mathrm{c}}$ & $6.90 \pm 0.020^{\mathrm{c}}$ & $6.89 \pm 0.035^{\mathrm{c}}$ & $7.37 \pm 0.012^{\mathrm{c}}$ & $9.59 \pm 0.030^{\mathrm{c}}$ \\
\hline 12 & $10.56 \pm 0.04^{\mathrm{d}}$ & $7.87 \pm 0.017^{\mathrm{d}}$ & $7.86 \pm 0.010^{\mathrm{d}}$ & $8.68 \pm 0.026^{\mathrm{d}}$ & $11.02 \pm 0.042^{\mathrm{d}}$ \\
\hline
\end{tabular}

Values show means of triplicate analysis \pm SD. Figures with different superscript down the column are significantly different $(P<0.05)$.

Table 2: Titratable acidity (\%) of flavoured and non-flavoured lactic acid bacterial tigernut drink stored at ambient temperature

\begin{tabular}{|c|c|c|c|c|c|}
\hline Week & $\mathbf{3 \%}$ Ginger & $\mathbf{5 \%}$ Ginger & $\mathbf{3 \%}$ Garlic & $\mathbf{5 \%}^{\text {Garlic }}$ & No Flavour \\
\hline 0 & $7.46 \pm 0.015^{\mathrm{a}}$ & $6.50 \pm 0.026^{\mathrm{a}}$ & $6.66 \pm 0.020^{\mathrm{a}}$ & $6.14 \pm 0.015^{\mathrm{a}}$ & $6.37 \pm 0.020^{\mathrm{a}}$ \\
\hline 4 & $8.24 \pm 0.020^{\mathrm{b}}$ & $6.79 \pm 0.010^{\mathrm{b}}$ & $7.65 \pm 0.032^{\mathrm{b}}$ & $6.60 \pm 0.025^{\mathrm{b}}$ & $8.34 \pm 0.020^{\mathrm{b}}$ \\
\hline 8 & $10.38 \pm 0.025^{\mathrm{c}}$ & $9.38 \pm 0.020^{\mathrm{c}}$ & $10.25 \pm 0.017^{\mathrm{c}}$ & $9.88 \pm 0.035^{\mathrm{c}}$ & $11.46 \pm 0.021^{\mathrm{c}}$ \\
\hline 12 & $13.91 \pm 0.031^{\mathrm{d}}$ & $10.03 \pm 0.031^{\mathrm{d}}$ & $14.77 \pm 0.035^{\mathrm{d}}$ & $10.11 \pm 0.030^{\mathrm{d}}$ & $17.11 \pm 0.026^{\mathrm{d}}$ \\
\hline
\end{tabular}

Values show means of triplicate analysis $\pm S D$. Figures with different superscript down the column are significantly different $(P<0.05)$.

As shown overleaf in Table $3 \& 4$, there was increasing lactic acid bacterial count during ambient and refrigeration temperature storage in both flavoured and non-flavoured tigernut-milk drink. The non-flavoured lactic acid bacterial tigernut-milk drink recorded higher LAB count each week monitored compared to ginger and garlic flavoured lactic acid bacterial tigernut-milk drink throughout the storage period.

Table 3: Lactic acid bacterial count (Log10CFU/ml) in flavoured and non-flavoured lactic acid bacterial tigernut-milk drink stored at ambient temperature.

\begin{tabular}{|c|c|c|c|c|c|}
\hline Week & 3\% Ginger & $\mathbf{5 \% \text { Ginger }}$ & $\mathbf{3 \% \text { Garlic }}$ & $\mathbf{5 \%}^{\text {Garlic }}$ & No Flavour \\
\hline 0 & $5.17 \pm 0.015^{\mathrm{a}}$ & $5.98 \pm 0.02^{\mathrm{b}}$ & $5.88 \pm 0.026^{\mathrm{b}}$ & $5.82 \pm 0.035^{\mathrm{b}}$ & $5.89 \pm 0.031^{\mathrm{a}}$ \\
\hline 4 & $5.13 \pm 0.025^{\mathrm{a}}$ & $5.74 \pm 0.021^{\mathrm{a}}$ & $5.10 \pm 0.118^{\mathrm{a}}$ & $5.16 \pm 0.021^{\mathrm{a}}$ & $6.13 \pm 0.066^{\mathrm{b}}$ \\
\hline 8 & $7.87 \pm 0.030^{\mathrm{c}}$ & $7.76 \pm 0.031^{\mathrm{c}}$ & $7.91 \pm 0.026^{\mathrm{c}}$ & $7.89 \pm 0.091^{\mathrm{c}}$ & $8.70 \pm 0.035^{\mathrm{c}}$ \\
\hline 12 & $7.80 \pm 0.026^{\mathrm{b}}$ & $7.72 \pm 0.020^{\mathrm{c}}$ & $8.94 \pm 0.040^{\mathrm{d}}$ & $7.94 \pm 0.046^{\mathrm{c}}$ & $9.87 \pm 0.030^{\mathrm{d}}$ \\
\hline
\end{tabular}

Values show means of triplicate analysis $\pm S D$. Figures with different superscript down the column are significantly different $(P<0.05)$. 


\section{Current Trends in Biomedical Engineering \& Biosciences}

Table 4: Lactic acid bacterial count (Log10CFU/ml) in flavoured and non-flavoured lactic acid bacterial tigernut- milk drink stored at refrigeration temperature.

\begin{tabular}{|c|c|c|c|c|c|}
\hline Week & $\mathbf{3 \%}$ Ginger & $\mathbf{5 \%}$ Ginger & $\mathbf{3 \%}$ Garlic & $\mathbf{5 \%}^{\text {Garlic }}$ & No Flavour \\
\hline 0 & $5.05 \pm 0.051^{\mathrm{a}}$ & $5.92 \pm 0.051^{\mathrm{b}}$ & $5.96 \pm 0.071^{\mathrm{b}}$ & $5.89 \pm 0.123^{\mathrm{a}}$ & $5.88 \pm 0.067^{\mathrm{a}}$ \\
\hline 4 & $5.15 \pm 0.066^{\mathrm{a}}$ & $5.14 \pm 0.191^{\mathrm{a}}$ & $5.64 \pm 0.101^{\mathrm{a}}$ & $5.96 \pm 0.082^{\mathrm{a}}$ & $6.89 \pm 0.095^{\mathrm{b}}$ \\
\hline 8 & $6.97 \pm 0.098^{\mathrm{b}}$ & $5.19 \pm 0.056^{\mathrm{a}}$ & $6.17 \pm 0.109^{\mathrm{c}}$ & $6.77 \pm 0.076^{\mathrm{b}}$ & $8.70 \pm 0.078^{\mathrm{c}}$ \\
\hline 12 & $7.83 \pm 0.075^{\mathrm{c}}$ & $6.70 \pm 0.092^{\mathrm{c}}$ & $7.04 \pm 0.095^{\mathrm{d}}$ & $7.87 \pm 0.076 \mathrm{c}$ & $8.10 \pm 0.085^{\mathrm{d}}$ \\
\hline
\end{tabular}

Values show means of triplicate analysis $\pm S D$. Figures with different superscript down the column are significantly different $(P<0.05)$.

The $3 \%(\mathrm{w} / \mathrm{v})$ garlic flavoured and $3 \%(\mathrm{w} / \mathrm{v})$ ginger flavoured lactic acid bacterial tigernut-milk drink stored at ambient and refrigeration temperature maintained a higher LAB count than the $5 \%(\mathrm{w} / \mathrm{v})$ garlic flavoured and $5 \%(\mathrm{w} / \mathrm{v})$ ginger flavoured lactic acid bacterial tigernut-milk drink also stored at ambient and refrigeration temperature. It could be that LAB in the $3 \%(\mathrm{w} / \mathrm{v})$ ginger flavoured and $3 \%(\mathrm{w} / \mathrm{v})$ garlic flavoured lactic acid bacterial tigernut-milk tolerated low concentration flavouring agent better than the $5 \%(\mathrm{w} / \mathrm{v})$ ginger flavoured and $5 \%(\mathrm{w} / \mathrm{v})$ garlic flavoured lactic acid bacterial tigernut-milk drink. At Week 6, only the non-flavoured lactic acid bacterial tigernutmilk drink stored at refrigeration and ambient temperature met the recommended minimum of biovalue (MBV) 6 log10CFU/ $\mathrm{ml}$ for dairy probiotic products. The garlic and ginger flavoured lactic acid bacterial tigernut-milk drink stored at refrigeration and ambient temperature met the MBV requirement at Week 8.

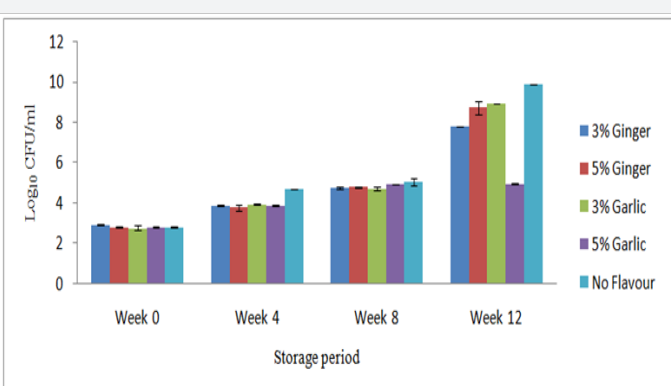

Figure 3: Total heterotrophic bacterial count in flavoured and non-flavoured lactic acid bacterial tigernut-milk drink stored at ambient temperature.

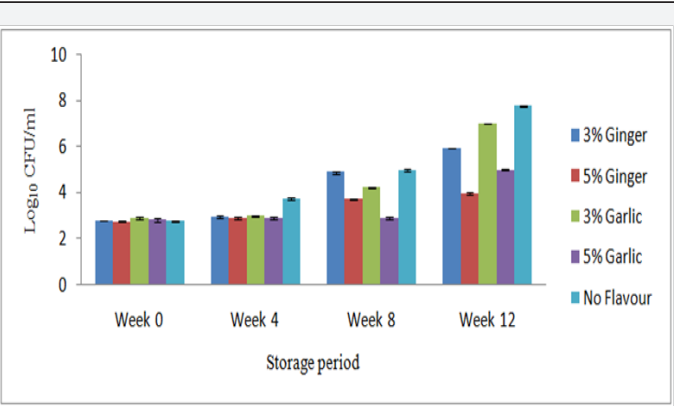

Figure 4: Total heterotrophic bacterial count in flavoured and non-flavoured lactic acid bacterial tigernut-milk drink stored at refrigeration temperature.

Figure 3 \& 4 represent the total heterotrophic bacterial count monitored at 4 weeks interval for a period of 12 weeks during storage at ambient and refrigeration temperature, respectively. In terms of total heterotrophic bacterial count, ambient temperature storage had minimal variation in the flavoured and non-flavoured lactic acid bacterial tigernut-milk drink compared to refrigeration temperature storage. This study has shown that the shelf life of all the flavoured lactic acid bacterial tigernut-milk preparations including the non-flavoured lactic acid bacterial tigernut-milk drink is 8 weeks irrespective of any of the two storage conditions based on the standard set by Codex Alimentarius Commission regarding safe dairy milk which stipulate that the level of microorganisms in the product must be below $2.0 \times 105 \mathrm{CFU} / \mathrm{ml}$ i.e. $5.30 \log 10 \mathrm{CFU} / \mathrm{ml}$ for it to be considered safe and acceptable for human consumption [24]. However, at Week 12 during refrigeration temperature storage of non-flavoured and flavoured lactic acid bacterial tigernutmilk drink, only $5 \%(\mathrm{w} / \mathrm{v})$ ginger flavoured lactic acid bacterial tigernut-milk drink and 5\%(w/v) garlic flavoured lactic acid bacterial tigernut-milk drink having a total heterotrophic bacterial count $3.92 \log 10 \mathrm{CFU} / \mathrm{ml}$ and $4.96 \log 10 \mathrm{CFU} / \mathrm{ml}$, respectively is considered safe for human consumption. All the flavoured lactic acid bacterial tigernut-milk drink including the non-flavoured stored at ambient temperature at Week 12 are unsafe for human consumption except $5 \%(\mathrm{w} / \mathrm{v})$ garlic flavoured tigernut-milk drink which had a total heterotrophic bacterial count $4.95 \log 10 \mathrm{CFU} / \mathrm{ml}$. This is an indication that refrigeration storage and higher concentration of the flavouring agent (ginger and garlic) contributed significantly in extending the shelf life of these potential probiotic products. The result in this study is in agreement with $[27,28]$ which demonstrated that Lactobacillus acidophilus and Lactobacillus plantarum considerably tolerated antimicrobial effect from garlic. In this study, the viability of LAB which includes Streptococcus thermophilus in garlic flavoured lactic acid bacterial tigernut-milk is in agreement with successful production of garlic flavoured yoghurt which is a similar product [29]. The viability of LAB in ginger flavoured lactic acid bacterial tigernut-milk drink offers some useful information regarding ginger spiced yoghurt which is a similar product [30].

At Week 0, 4, 8 and 12 during ambient temperature storage of both flavoured and non-flavoured lactic acid bacterial tigernut-milk drink, maximum heterotrophic bacterial count $2.92 \log 10 \mathrm{CFU} / \mathrm{ml}, 4.70 \log 10 \mathrm{CFU} / \mathrm{ml}, 5.05 \log 10 \mathrm{CFU} / \mathrm{ml}$ and $9.88 \log 10 \mathrm{CFU} / \mathrm{ml}$, respectively were recorded. Maximum heterotrophic bacterial count $2.87 \log 10 \mathrm{CFU} / \mathrm{ml}, 3.73 \log 10 \mathrm{CFU} /$ $\mathrm{ml}, 4.94 \log 10 \mathrm{CFU} / \mathrm{ml}$ and $7.73 \log 10 \mathrm{CFU} / \mathrm{ml}$ were also recorded 
at Week $0,4,8$ and 12 , respectively during refrigeration temperature storage of flavoured and non-flavoured lactic acid bacterial tigernut-milk drink. The result of this study shows that refrigeration temperature storage is better than ambient temperature storage in terms of shelf life of these products possibly as a result of refrigeration temperature not favouring rapid growth of heterotrophic bacteria that can cause spoilage of both the flavoured and non-flavoured lactic acid bacterial tigernut-milk drink. Although, this result is similar to that of [24], there is improvement in terms of longer shelf life of the flavoured and non-flavoured lactic acid bacterial tigernut-milk drink from 14 days reported by [24] to 8 weeks. The reason for this observation could be as a result of ginger and garlic added to the lactic acid bacterial tigernut-milk drink which functioned as a natural preservative. In addition, the presence of LAB in the flavoured and non-flavoured tigernut-milk drink which produces antimicrobial substances could also have contributed in extending the shelf life of these potential probiotic products [31,32] (Table 5 \& 6).

Table 5: Percentage lactic acid produced in flavoured and non-flavoured lactic acid bacterial tigernut-milk drink stored at refrigeration temperature.

\begin{tabular}{|c|c|c|c|c|c|}
\hline Week & 3\% Ginger & $\mathbf{5 \% \text { Ginger }}$ & $\mathbf{3 \%}$ Garlic & $\mathbf{5 \%}$ Garlic & No Flavour \\
\hline 0 & $9.05 \pm 0.061^{\mathrm{a}}$ & $7.75 \pm 0.060^{\mathrm{a}}$ & $7.75 \pm 0.050^{\mathrm{a}}$ & $7.31 \pm 0.061^{\mathrm{a}}$ & $7.53 \pm 0.076^{\mathrm{a}}$ \\
\hline 4 & $9.86 \pm 0.116^{\mathrm{b}}$ & $8.03 \pm 0.085^{\mathrm{b}}$ & $8.01 \pm 0.071^{\mathrm{b}}$ & $7.45 \pm 0.046^{\mathrm{b}}$ & $10.04 \pm 0.056^{\mathrm{b}}$ \\
\hline 8 & $11.23 \pm 0.061^{\mathrm{c}}$ & $8.26 \pm 0.065^{\mathrm{c}}$ & $8.27 \pm 0.036^{\mathrm{c}}$ & $8.83 \pm 0.078^{\mathrm{c}}$ & $12.83 \pm 0.056^{\mathrm{c}}$ \\
\hline 12 & $12.66 \pm 0.118^{\mathrm{d}}$ & $9.32 \pm 0.073^{\mathrm{d}}$ & $9.42 \pm 0.092^{\mathrm{d}}$ & $10.44 \pm 0.072^{\mathrm{d}}$ & $13.71 \pm 0.040^{\mathrm{d}}$ \\
\hline
\end{tabular}

Values show means of triplicate analysis $\pm S D$. Figures with different superscript down the column are significantly different $(P<0.05)$.

Table 6: Percentage lactic acid produced in flavoured and non-flavoured lactic acid bacterial tigernut-milk drink stored at ambient temperature.

\begin{tabular}{|c|c|c|c|c|c|}
\hline Week & $3 \%$ Ginger & 5\% Ginger & 3\% Garlic & 5\% Garlic & No Flavour \\
\hline 0 & $8.95 \pm 0.014^{\mathrm{a}}$ & $7.80 \pm 0.056^{\mathrm{a}}$ & $7.98 \pm 0.070^{\mathrm{a}}$ & $7.35 \pm 0.082^{\mathrm{a}}$ & $7.46 \pm 0.085^{\mathrm{a}}$ \\
\hline 4 & $9.87 \pm 0.047^{b}$ & $8.14 \pm 0.073^{b}$ & $9.18 \pm 0.046^{\mathrm{b}}$ & $7.92 \pm 0.064^{\mathrm{b}}$ & $12.51 \pm 0.03^{b}$ \\
\hline 8 & $12.45 \pm 0.103^{c}$ & $11.26 \pm 0.045^{c}$ & $12.32 \pm 0.076^{c}$ & $11.85 \pm 0.108^{c}$ & $15.16 \pm 0.104^{c}$ \\
\hline 12 & $16.69 \pm 0.014^{\mathrm{d}}$ & $12.05 \pm 0.070^{\mathrm{d}}$ & $17.72 \pm 0.040^{\mathrm{d}}$ & $12.13 \pm 0.064^{\mathrm{d}}$ & $20.53 \pm 0.185^{\mathrm{d}}$ \\
\hline
\end{tabular}

Values show means of triplicate analysis $\pm S D$. Figures with different superscript down the column are significantly different $(P<0.05)$.

Shelf life study carried out by [26] which involved lactic acid fermentation of milk blends comprising soybean milk, coconut milk and African yam bean milk revealed that refrigeration temperature storage for 28 days and ambient temperature storage for 21 days ensured that viability of LAB was maintained as well as its physicochemical properties as a potential probiotic product.

The result shown in Table $5 \& 6$ is the percentage lactic acid produced during refrigeration and ambient temperature storage, respectively of flavoured and non-flavoured lactic acid bacterial tigernut-milk drink. Lactic acid is the major product of homofermentative LAB during lactic acid bacteria fermentation. Lactic acid has been commercialized for different industrial applications [33]. The increase in percentage lactic acid produced during storage of both flavoured and non-flavoured lactic acid bacterial tigernut-milk drink is an indication that population of LAB was increasing during the storage period which was confirmed by the result presented in Table $3 \& 4$.

The non-flavoured lactic acid bacterial tigernut-milk drink recorded the highest percentage lactic acid produced by LAB each week monitored throughout the period of storage at refrigeration and ambient temperature except at Week 0 when $3 \%(\mathrm{w} / \mathrm{v})$ ginger flavoured lactic acid bacterial tigernut-milk drink at both storage conditions recorded the highest percentage lactic acid. Lower percentage lactic acid in the non-flavoured lactic acid bacterial tigernut-milk drink at Week 0 could be as a result of LAB in the non-flavoured tigernut-milk drink being at the lag phase which rapidly entered the log phase before LAB in the flavoured lactic acid bacterial tigernut-milk. The antimicrobial properties of ginger and garlic could have played a role in the percentage lactic acid produced in the flavoured tigernut-milk drink. This could be the reason why higher percentage lactic acid was produced by LAB in the non-flavoured lactic acid bacterial tigernut in subsequent weeks compared to ginger flavoured and garlic flavoured tigernut-milk drink during storage in both ambient and refrigeration temperature. Comparison between ambient and refrigeration storage in terms of percentage lactic acid produced by LAB in the non-flavoured and flavoured lactic acid bacterial tigernut-milk drink shows that ambient temperature storage favoured the production of higher percentage lactic acid compared to refrigeration temperature storage. However, the lactic acid bacterial count shows that little difference exist between samples stored at ambient and refrigeration temperature.

\section{Conclusion}

Ambient and refrigeration temperature storage seem to support probiotic stability in flavoured and non-flavoured lactic acid bacterial tigernut-milk drink while refrigeration temperature storage, synergistic effect of lactic acid bacteria and natural preservatives namely ginger and garlic might have 
resulted in prolonged shelf life of these potential probiotic products and still maintained probiotic stability. Due to financial limitations, the use of culture-independent methods in order to enumerate viable but not culturable (VBNC) bacteria present in the flavoured and non-flavoured tigernut drink were not adopted in this study [34].

\section{Acknowledgement}

I hereby express appreciation to Dr. F. A. Orji of Federal Institute of Industrial Research Oshodi (FIIRO) Lagos, Nigeria for his wonderful assistance in this research.

\section{References}

1. Gambo A, Dáu A (2014) Tigernut (Cyperus esculentus): Composition, products, uses and health benefits-A review. Bayero Journal of Pure and Applied Science 7(1): 56-61.

2. Belewu MA, Abodunrin OA (2006) Preparation of kunu from unexploited rich food source: Tigernut (Cyperus esculentus). World Journal of Dairy and Food Sciences (1): 109-111.

3. Sanful RE (2009) The use of tiger-nut (Cyperus esculentus), cow milk and their composite as substrates for yoghurt production. Pakistan Journal of Nutrition 8(6): 755-758.

4. Adejuyitan JA (2011) Tigernut processing: Its food uses and health benefits. American Journal of Food Technology 6(3): 197-201.

5. Wakil SM, Ayenuro OT, Oyinlola KA (2014) Microbiological and nutritional assessment of starter-developed fermented tigernut milk. Food and Nutrition Sciences 5: 495-506.

6. El-Shenawy M, Abd El-Aziz M, El-kholy WI, Fouad MT (2012) Probiotic yoghurt manufactured with tiger-nut extract (Cyperus esculentus) as a functional dairy food. Journal of Agricultural Research and Natural Resources 1(2): 20-31.

7. Mokoena MP, Mutanda T, Olaniran AO (2016) Perspectives on the probiotic potential of lactic acid bacteria from African traditional fermented foods and beverages. Food and Nutrition Research 60: 29630- 29642 .

8. Lisak K, Lenc M, Jeličić I, Božanić R (2012) Sensory evaluation of the strawberry flavored yoghurt with stevia and sucrose addition. Croatian Journal of Food Technology, Biotechnology and Nutrition 7: 39-43.

9. Adubofuor J, Dzigbordi B, Wireku-Manu FD (2014) Comparative studies on the qualities of seven brands of vanilla-flavoured stirred yoghurts produced within the Kumasi metropolis of Ghana. International Food Research Journal 21(3): 1243-1248.

10. Moshksar L, Beheshti MKD, Hossein M, Marhamatizadeh (2014) Production of honied-probiotic milk by Bifidobacterium bifidum. International Journal of Current Life Sciences 4(12): 13458-13463.

11. Oluwatoyin A (2014) Physicochemical characterization and antioxidant properties of the seeds and oils of ginger (Zingiber officinale) and garlic (Allium sativum). Science Journal of Chemistry 2(6): 44-50.

12. Offei-Okyne R, Patterson J, Walker LT, Verghese M (2015) Processing effects on phytochemical content and antioxidative potential of ginger (Zingiber officinale). Food and Nutrition Sciences 6: 445-451.

13. Corzo-Martinez M, Corzo N, Villamiel M (2007) Biological properties of onions and garlic. Trends in Food Science and Technologies 18: 609615 .

14. Malhotra S, Singh AP (2003) Medicinal properties of ginger (Zingiber officinale Rosc.). Natural Product Radiance 2(6): 296-301.
15. Mortazavian AM, Mohammadu R, Sohrabvandi S (2012) Delivery of probiotic microorganisms into gastrointestinal tract by food products in New advances in the basic and clinical gastroenterology Prof. Tormasz Brzozowski (Ed.).

16. http://www.intechopen.com/books/new-advances-in-the-basic-andclinical gastroenterology/

17. Marhamatizadeh MH, Afrasiabi S, Rezazadeh S, Marhamati Z (2011) Effect of spearminton the growth of Lactobacillus acidophilus and Bifidobacterium bifidum in probiotic milk and yoghurt. African Journal of Food Science 5(13): 747-753.

18. Mortazavian AM, Ehsani MR, Mousavi SM, Rezaei K, Sohrabvandi S, et al. (2007) Effect of refrigerated storage temperature on the viability of probiotic micro-organisms in yogurt. International Journal of Dairy Technology 60 (2): 123-127.

19. http://www.woodheadpublishingonline.com

20. Tamang JP, Shin DH, Jung SJ, Chae SW (2016) Functional properties of microorganisms in fermented foods. Frontiers in Microbiology 7(578): $1-13$.

21.Zyzelewicz D, Nebesny E, Motyl I, Libudzisz Z (2010) Effect of milk chocolate supplementation with lyophilized lactobacillus cells on its attributes. Czechoslovakia Journal of Food Sciences 28: 392-406.

22. Oluwajoba SO, Akinyosoye FA, Oyetayo VO (2013) In vitro screening and selection of probiotic lactic acid bacteria isolated from spontaneously fermenting kunu-zaki. Advances in Microbiology 3: 309-316.

23. Ojokoh AO Daramola MD (2012) Evaluation of lima bean flour fermented with Lactobacillus sp. as a probiotic food. African Journal of Food Science 6 (13): 352-361.

24. Nwobosi PNU, Isu NR, Agarry 00 (2013) Influence of pasteurization and use of natural tropical preservatives on the quality attributes of tigernut drink during storage. International Journal of Food and Nutritional Sciences 2(1): 27-32.

25. Udeozor LO, Awonorin SO (2014) Comparative microbial analysis and storage of tigernut-soy milk extract. Asutin Journal of Nutrition and Food Sciences 2(5): 1-6.

26. http://www.intechopen.com/books/new

27. Adeniran HA, Olaniyi OI, Abiose SH (2016) Viability and effect of probiotic lactic acid bacteria isolated from locally fermented foods in a non-dairy beverage from African yam bean. Ife Journal of Technology 24(1): 6-10.

28. Marhamatizade MH (2015) Effect of garlic and dill extract on yoghurt probiotic bacteria (Bifidobacterium bifidum and Lactobacillus acidophilus) and their role in rat's triglycerides and cholesterol. Bulletin of Environment, Pharmacology and Life Sciences 4(3): 10-15.

29. Booyens J, Thantsha MS (2013) Antibacterial effect of hydrosoluble extracts of garlic (Allium sativum) against Bifidobacterium spp. and Lactobacillus acidophilus. African Journal of Microbiology Research 7(8): 669-677.

30. Qureshi AM, Hassan SY, Sulariya AM, Rashid, AA (2011) Preparation and nutritional evaluation of garlic based yoghurt. Science International 23 (1): 59-62.

31. Ihemeje A, Nwachukwu CN, Ekwe CC (2015) Production and quality evaluation of flavoured yoghurts using carrot, pineapple and spiced yoghurts using ginger and pepper fruit. African Journal of Food Science 9(3): 163-169.

32. Hasan HF, Hamzah AM, Zghair ZR (2013) Study the comparative effect between Cyperus esculentus seeds extract and gentamicin on induced endometritis in mice. Journal of Physics: Conference Series 7(7):40-47. 
33. Caplice E, Fitzgerald GF (1999) Food fermentation: Role of microorganisms in food production and preservation. International Journal of Food Microbiology 50: 131-149.
34. Abdel-Rahman MA, Tashiro Y, Sonomoto, K. (2013) Recent advances in lactic acid production by microbial fermentation processes. Biotechnology Advances (31): 877-902.

\section{Your next submission with Juniper Publishers will reach you the below assets}

- Quality Editorial service

- Swift Peer Review

- Reprints availability

- E-prints Service

- Manuscript Podcast for convenient understanding

- Global attainment for your research

- Manuscript accessibility in different formats

( Pdf, E-pub, Full Text, Audio)

- Unceasing customer service

Track the below URL for one-step submission https://juniperpublishers.com/online-submission.php 